九州大学学術情報リポジトリ

Kyushu University Institutional Repository

\title{
Reducing Food Safety Risk: Experiences from the Adoption of Good Agricultural Practices in China
}

Song, Min

East Ásia Center for Agricultural Resources \& Environment Studies, Institute of Agricultural Resources and Regional Planning, Chinese Academy of Agricultural Sciences

Gao, Xiao-Ou

East Asia Center for Agricultural Resources \& Environment Studies, Institute of Agricultural Resources and Regional Planning, Chinese Academy of Agricultural Sciences

Liu, Li-Jun

East Asia Center for Agricultural Resources \& Environment Studies, Institute of Agricultural Resources and Regional Planning, Chinese Academy of Agricultural Sciences

Nanseki, Teruaki

Laboratory of Farm Management, Department of Agricultural and Resource Economics, Faculty of Agriculture, Kyushu University

https://doi.org/10.5109/18855

出版情報：九州大学大学院農学研究院紀要. 55 (2)，pp. 379-385，2010-10-29. Faculty of Agriculture, Kyushu University

バージョン :

権利関係 : 


\title{
Reducing Food Safety Risk: Experiences from the Adoption of Good Agricultural Practices in China
}

\author{
Min SONG ${ }^{1}$, Xiao-Ou GAO ${ }^{1}$, Li-Jun LIU ${ }^{1}$ \\ and Teruaki NANSEKI ${ }^{2}$
}

\author{
East-Asia Center for Agricultural Resources \& Environment Studies, Institute of Agricultural Resources and \\ Regional Planning, Chinese Academy of Agricultural Sciences, No.12 \\ Zhongguancun Nandajie Beijing, P.R.China 100081 \\ (Received June 23, 2010 and accepted July 9, 2010)
}

\begin{abstract}
Foodborne diseases outbreak frequently in recent years in China, which stimulate consumer's increasing concerns toward food quality and safety. In order to ensure food safety and rebuild consumer confidence, the Chinese government has taken a series of remedy measures. As an effective way of reducing food safety risk in the headstream of the food supply chain, Good Agricultural Practice (GAP) is attracting more and more attention and extending rapidly, especially well accepted by those enterprise applicants from the coastal provinces. However, it faces the challenge that how to popularize the certification widely among the small-scale farming households throughout China.
\end{abstract}

Keywords: Good Agricultural Practices (GAP); Risk; Traceability; Food Safety; China

\section{INTRODUCTION}

As a consequence of well-known foodborne diseases' outbreak, food safety is becoming a major global concern. In order to ensure food safety and rebuild consumer confidence, a series of modern approaches to reducing risk through the food supply chain are being approved around the world. For example, Good Agricultural Practices (GAP) is implemented to control risk in agricultural production, Hazard Analysis Critical Control Point (HACCP) and Good Manufacturing Practice (GMP) are performed to steer risk during food processing, packing and transporting. And food traceability system is used to accurately trace food back to its source or origin.

GAP, refer to a collection of principles to apply for on-farm production and post-production processes, resulting in safe and healthy food and non-food agricultural products, while taking into account economical, social and environmental sustainability (FAO), is widespread supported by government, farmer, firm, retailer and consumer. As early as 1997, following the food safety scare on Bovine Spongiform Encephalopathy (BSE) and consumers' growing concern on food safety, the EuroRetailer Produce Working Group GAP (EUREPGAP) was originally initiated by retailers belonging to the EUREP and developed into an equal partnership of agricultural producers and their retail customers. Now dealers, producers, suppliers and supporting members from the agricultural service area belong to the EUREPGAP, which has approximately 37,000 members in 65 countries (Frankfurt, 2006). In 2007, the EUREPGAP changed its

East Asia Center for Agricultural Resources \& Environment Studies, Institute of Agricultural Resources and Regional Planning, Chinese Academy of Agricultural Sciences, China P.R.

2 Laboratory of Farm Management, Department of Agricultural and Resource Economics, Faculty of Agriculture, Kyushu University, Japan name to GLOBALGAP to reflect its increasing global scope. The existing facts show that GAP as an effective strategy to assure food safety has been ushered in both advanced countries and developing countries (Jie et al., 2009).

Over the past few years China also experiences frequent food safety scares generated by pesticide residue, abuse of addictive, and microbe contamination which increase the urgency of an effective approach to safeguard food safety, especially to ensure food safety in agriculture. With the demand for safe foods both in domestic and export market, China has already set up and carried out China Good Agricultural Practices (ChinaGAP) since 2005, which is developing rapidly by means of the promotion of government.

\section{FOOD SAFETY RISK}

\section{Increase of food safety risk}

Food safety risk exists in the whole food supply chain and could not be avoided and totally eliminated (Nanseki, 2008ab). Further, with the flourishing of chemical industry, extending of food supply chain and deteriorating of environment, food safety risk is significantly increasing. Fig. 1 shows one of examples of the dairy supply chain in China. According to the survey carried out in Hebei province of China in September 2008, the dairy supply chain consisted of the following participants: feed factory, drugstore, dairy farmers, milk station, dairy factories, other factories (confectionary plan, bakery and so on), and market. The survey shows that food safety risk exists at every step in the supply chain. At the upstream, feed factory and drugstore may supply some illegal feed additives and forbidden medicine to dairy farmers who are lack of knowledge and information about irregular feed additives and veterinary, which will result in potential risk rising. In the second step, use of antibiotics, milking of diseased cow and blast of pestilence will also 


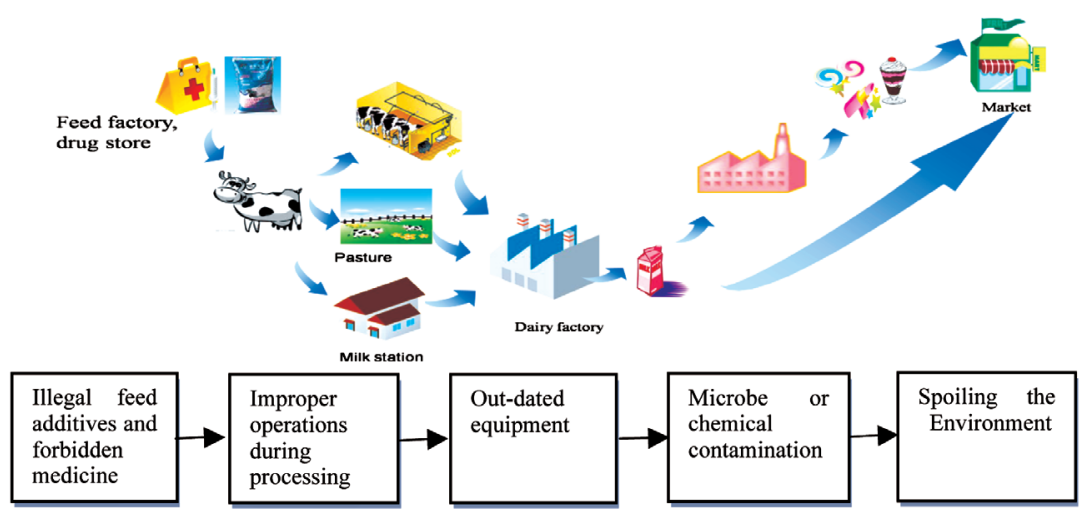

Fig. 1. Dairy supply chain in China

Source: A survey carried out in Hebei province of China in September 2008. Edited by authors.

cause risk in raw milk. In the third step, it is hard to examine milk quality and ensure milk safety with outdated equipment in milk stations and small-scale dairy processing factories. Meanwhile, microbe or chemical contamination always takes place during processing, packaging, storage and transportation. At the last, bad circumstances of the market easily brings about contamination too. Obviously, as the advancement of modern industry, the food supply chain is extending and participants group involved in the food chain is becoming more and more complicated, which lead to risk increasing.

\section{The impact of food safety risk on consumer}

As a result of food safety risk increase and foodborne diseases outbreak, Chinese consumers were hurt both physically and mentally.

According to the bulletin of China's Ministry of Health $(\mathrm{MOH})$, the number of Food poisoning cases was going up in the last 5 years. 2,453 cases relating to serious food poisoning incidents were received during 2005, 42,876 people involved and 255 died. Microbe contamination and chemical contamination are two main reasons for food poisoning, which hurt consumers' health badly. Table 1 shows the serious food poisoning cases issued by MOH from 2001 to 2005.

Also, consumers lost their confidence on food safety by food safety accidents. A survey in the dairy market of Beijing was performed in October 2008. When respond-

Table 1. Serious Food poisoning cases issued by MOH from 2001 to 2005

\begin{tabular}{cccc}
\hline Year & $\begin{array}{c}\text { Food poisoning } \\
\text { cases }\end{array}$ & $\begin{array}{c}\text { Involved } \\
\text { persons }\end{array}$ & Dead persons \\
\hline 2001 & 624 & 20,124 & 143 \\
2002 & 464 & 11,572 & 68 \\
2003 & 1,481 & 29,660 & 262 \\
2004 & 2,305 & 42,876 & 255 \\
2005 & 2,453 & 32,553 & 381 \\
\hline
\end{tabular}

Source of data: Statistical Bulletin of China's Health Service (2001-2005), MOH,

http://www.moh.gov.cn/publicfiles/business/htmlfiles/zwgkzt/ pgb/index.htm

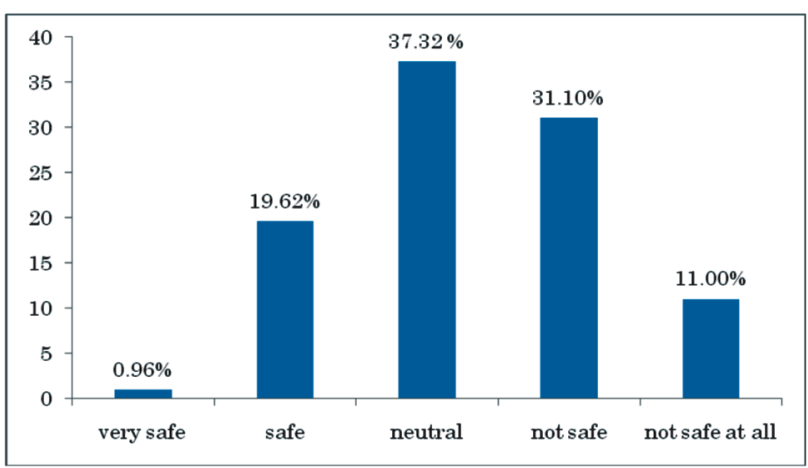

Fig. 2. Consumers' attitudes toward food safety Source: Author's own survey (2008) in the dairy market of Beijing

Note:n=209

ents were asked about their perception of food safety in China, among 209 valid samples, 23 (11.00\%) respondents didn't think food was safe at all, 65 (31.10\%) respondents thought food was mostly unsafe, 78 (37.32\%) respondents was neutral, 41 (19.62\%) respondents thought food was safe and only $2(0.96 \%)$ respondents thought food was very safe. Obviously consumers have lost their confidence in food safety. The data in Fig. 2 shows Consumers' attitudes toward food safety.

\section{Consumer attitudes to ensuring food safety}

With the economic growth and the development of populated urbanized centers, Chinese consumers have showed more and more concern on food quality and safety (Bai et al., 2005). China has been adopting lots of measures and programs to introduce, extend, encourage and even mandate modern food safety approaches in food supply chain, like traceability system. In order to ensure food safety during 2008 Olympics, Beijing established and implemented a specialized food safety traceability system. For the purpose of making sure how consumers thought about traceability system, a consumer survey from December 2007 to January 2008 in the pork market of Beijing was carried out, all observations were selected randomly (Song et al., 2008). In the total 401 personally interviewed consumers, 388 samples were 


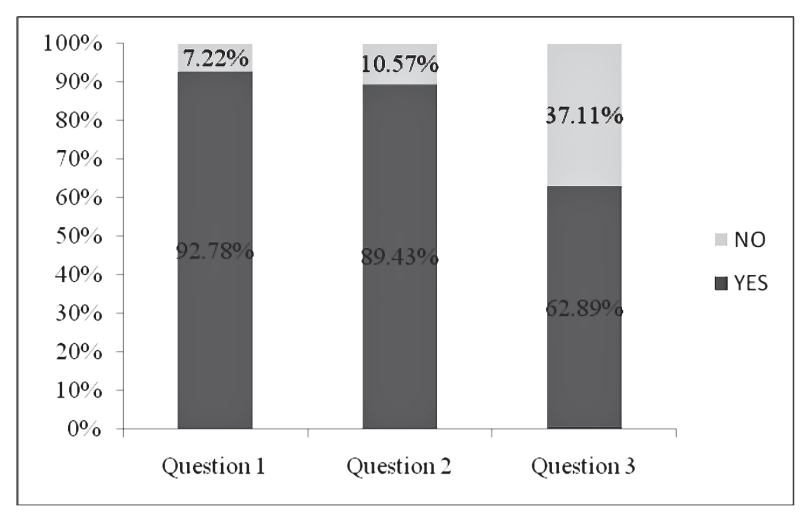

Fig. 3. Consumers' attitudes toward food traceability system. Source of data: Min Song et al. (2008)

Note: question 1: Do you think it is necessary to apply traceability system in pork? Question 2: Would you buy pork with traceability marks? Question 3: Could it increase your confidence on consuming food?

valid. The data shows that $92.8 \%$ of the respondents thought traceability system was necessary, $89.4 \%$ said they would buy traceability pork, and $62.9 \%$ thought the system could strengthen their confidence on consuming food (See Fig. 3). It confirmed that consumers desire effective approaches to ensure food safety.

\section{MODERN FOOD SAFETY APPROACHES AND GAP IN CHINA}

In order to minimize food safety risk, rebuild consumer confidence and improve competition of export agricultural production, government of China has implemented a series of certification to control risk in food supply chain (See Fig. 4). GAP certification, Safe Agro-food certification, Green Food certification, Organic Food certification and Feed certification are implemented during agricultural production. HACCP certification, Food Quality certification and Organic Food certification are implemented during food processing. Green Market certification is implemented during consuming. To facilitate the "agriculture standardization" and carry out specific management measures, GAP is taken as an effective way to lower food safety risks in agricultural production in the roots, and develops rapidly in China.

\section{History of ChinaGAP}

In April 2003, the Certification and Accreditation Administration of the People's Republic of China (CNCA) firstly brought forward to set up good agricultural practices in source of food chain and carry on translating and collecting related standards in early 2004, and then established an expert working group to draft and write related regulations and standards. Based on the control points and compliance criteria of EUREPGAP, GB/ T20014.1-11-2005 Good Agricultural Practice national standards (ChinaGAP) was promulgated by General Administration of Quality Supervision, Inspection and Quarantine of the People's Republic of China (AQSIQ) and Standardization Administration of the People's Republic of China (SAC). Now 24 ChinaGAP national standards have been formulated, including contents of combinable crops, fruit and vegetable, cattle and sheep, pig, poultry and aquiculture. And each standard includes the general rule, control point, appropriate regulation, checklist and basic procedures. In 2006, ChinaGAP Implementing Regulations (trail) (CNCA-N-004:2006) were issued to guide the GAP certification practices. Now, a unified GAP certification system has been established in China.

For the purpose of promoting ChinaGAP, CNCA and SAC initiated GAP standardization and accreditated pilot test work in 18 provinces, municipalities and autonomous regions of China in 2006. So far, the program has covered 552 pilot firms of 23 provinces, municipalities and autonomous regions. At the same time, in order to increase the exportation of Chinese agricultural products, CNCA has been coordinating with GLOBALGAP since 2005, and signed Memorandum of Technical Cooperation and Benchmark Comparison (mutual recognized) respectively in 2005 and 2006, and started practical cooperation on standard formulation and mutual recognition. With 2 years' efforts, ChinaGAP and GLOBAL GAP have completed regulation and standard documents evaluation on mutual conformity and efficiency, completed the evaluation of on-site testimony and peer review, successfully finished mutual recognition work and signed MOU on GAP Certification System Benchmark Comparison, marking ChinaGAP gain international mutual recognition (AQSIQ, 2009).

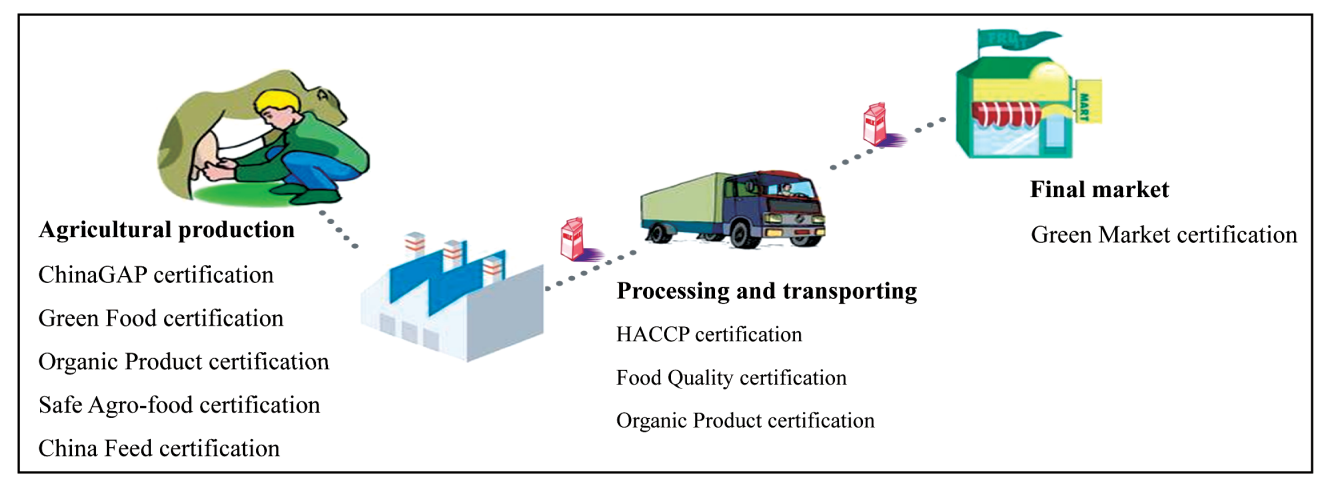

Fig. 4. Food-related certifications in China. Source: Edited by authors. 


\section{Implementation of ChinaGAP}

\section{Administrative regulatory system}

In China, regulatory management of certification is a responsibility shared between national and local government authorities. As the department undertaking unified management, supervision and overall coordination of certification and accreditation in China, CNCA was authorized by the State Council to manage, administer and authorize the ChinaGAP certification procedure and train inspectors, certification bodies (CB) and auditors. At the national level, CNCA is administered by AQSIQ,

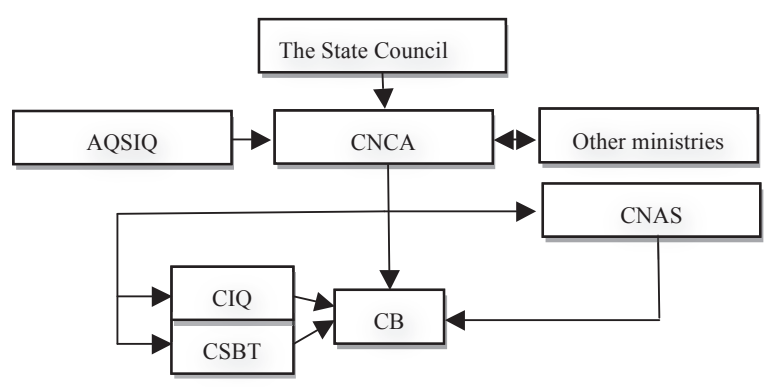

Fig. 5. Administrative regulatory system. Source: edited by authors. and cooperating with SAC, SAIC and other ministries in ChinaGAP certification work. At the local level, China Entry-Exit Inspection and Quarantine Bureau (CIQ) and Bureau of Quality and Technical Supervision (CSBT) supervise inspecting and certification bodies. At the same time, China National Accrediation Service for Conformity Assessment (CNAS) is authorized by CNCA to manage and administer inspecting and certification bodies who undertake concrete certification (See Fig. 5).

\section{Certification procedure}

According to China Quality Certification Center, the GAP certification procedure in China is introduced briefly as below (Table 2). There are four critical phases to complete the GAP certification. Basically, the applicant (farmer or enterprises) should indicate the wish of becoming certified to the certification body and then must submit the application and relevant documents to the certification body. After mutually confirmation and signing the contract, the certification body will inform the applicant of the date and time of the proposed inspection and requires the applicant to make necessary preparation, subsequently take actual inspection in the field. At the end of the inspection process, the inspector group

Table 2. China GAP certification procedure (The first revision for version 1.0)

\begin{tabular}{|c|c|c|c|}
\hline \multirow{2}{*}{ Phase } & \multirow{2}{*}{ Step } & \multicolumn{2}{|c|}{ Activities } \\
\hline & & Certification Body & Applicant \\
\hline \multirow{3}{*}{ Application } & Consultation & $\begin{array}{l}\text { Explain the basic rules and standards } \\
\text { related to CQC and GAP }\end{array}$ & Self-introduction \\
\hline & Reception & $\begin{array}{l}\text { Provide application tables and certifi- } \\
\text { cation standards; Evaluate the con- } \\
\text { tract; Specify the location, product } \\
\text { scope and certification expenditures }\end{array}$ & $\begin{array}{l}\text { Submit application materials and con- } \\
\text { firm the cost }\end{array}$ \\
\hline & Contracting & Sign the Contract & Sign the Contract \\
\hline \multirow{4}{*}{$\begin{array}{l}\text { Inspection and } \\
\text { Implementation }\end{array}$} & Preparation & $\begin{array}{l}\text { Notify the applicant of inspection let- } \\
\text { ter, tasks and programme }\end{array}$ & $\begin{array}{l}\text { Confirm the inspection date and pro- } \\
\text { gramme, prepare documents and } \\
\text { resources for actual inspection }\end{array}$ \\
\hline & Actual Inspection & $\begin{array}{l}\text { The inspectors check all the points } \\
\text { by requirements }\end{array}$ & Prepare the location and facilities \\
\hline & Sampling (applicable) & $\begin{array}{l}\text { The inspectors take samples for anal- } \\
\text { ysis }\end{array}$ & $\begin{array}{l}\text { Confirm the sampling method and } \\
\text { procedure }\end{array}$ \\
\hline & Recommendation & $\begin{array}{l}\text { Notify the applicant of results; } \\
\text { Reports the inappropriate parts } \\
\text { (applicable) }\end{array}$ & $\begin{array}{l}\text { Confirm the results; take measures to } \\
\text { correction (applicable) }\end{array}$ \\
\hline \multirow{5}{*}{$\begin{array}{l}\text { Review and } \\
\text { Approval }\end{array}$} & Initial Examination & $\begin{array}{l}\text { Initially examine the documents sub- } \\
\text { mitted by inspectors and check the } \\
\text { completeness and accuracy }\end{array}$ & Supplement materials (applicable ) \\
\hline & Evaluation & $\begin{array}{l}\text { Evaluate the quantifications eligibility } \\
\text { of applicant }\end{array}$ & \\
\hline & Approval & approved by the Agency head & \\
\hline & Certificating & Make the certificate & \\
\hline & Issuance & Mail the certificate to the applicant & Receive and confirm the certificate \\
\hline $\begin{array}{l}\text { Monitor and } \\
\text { Management }\end{array}$ & $\begin{array}{l}\text { Inspection without prior } \\
\text { notice }\end{array}$ & $\begin{array}{l}\text { Examine the checking list without } \\
\text { prior notice }\end{array}$ & Provide necessary resources \\
\hline $\begin{array}{l}\text { Alteration or } \\
\text { Renewal }\end{array}$ & $\begin{array}{l}\text { Alterations or Renewal } \\
\text { of Certification }\end{array}$ & $\begin{array}{l}\text { Process, evaluate and inspection dur- } \\
\text { ing the alteration }\end{array}$ & $\begin{array}{l}\text { Provide necessary resources for actu- } \\
\text { al inspection }\end{array}$ \\
\hline
\end{tabular}


Table 3. China GAP Certification Fees

\begin{tabular}{|c|c|c|}
\hline No. & Items & Fee standard (RMB) \\
\hline 1 & Application for the certification & 1000 \\
\hline 2 & On-site inspection & $3000 * X$ \\
\hline 3 & License and Registration & 2000 \\
\hline 4 & Monitor and Examination* & $\begin{array}{l}1500 \text { (Case 1: individual producer) } \\
5000 \text { (Case 2: group producers) }\end{array}$ \\
\hline 5 & Detection (conditional) & Additionally charged by detection organization \\
\hline 6 & Annual fee & 2000 \\
\hline
\end{tabular}

reviews the checklist form to determine whether the applicant meets the compliance criteria for GAP certification. If the applicant does not meet the requirements, the farmer will be informed in written with the actions he has to take to bring the field to acceptable standards. If the field meets the requirements, the Agency approves the certification and issues a certificate to the applicant. Even though completing the above steps, the Inspector of course may visit the farm during the period of growth of a crop to advise and monitor farm operations without prior notice. The certificate will expire after 3 years. If the applicant wants to alter and renew the certificate, the similar necessary processes would inevitably take place.

Data from China Quality Mark Certification Group shows that if an individual farmer (producer) wants to pass the GAP certification, he should pay at least 12,500 RMB to the certification body (see Table 3 ). The cost is just calculated on the simplest case and ignores many additional conditions. For grouping producers (enterprise), the minimum expenditure will go up to 17,500 . Then the annual registration fee will be charged 2,000 RMB. Given the high expenditure, obviously majority of Chinese small scale farmers would pay particular concern on the costs related to GAP certification. Most of them often cannot afford such economic burden when their annual net income per capita is only 4,761 RMB in 2008. However, a number of enterprises are aware that GAP certification has been the important condition of agricultural products for import and export; products with GAP certification are much more acceptable and competitive in domestic and overseas market. So the cost accrued in the GAP certification may not be hurdle to an enterprise applicant.

\section{Development of ChinaGAP}

ChinaGAP has become one of the most important approaches to ensuring agricultural production safety in China, with unified standards and perfect certification process. So far, 603 ChinaGAP certificates have been issued, covering 31 provinces, municipalities and autonomous regions. 15 certification bodies and 435 inspectors have been authorized by CNCA. The implementation of ChinaGAP certification has greatly spurred exportation, promoted the standardization of agricultural practice, and ensured the quality of agricultural products. However it only focused on export enterprises that only covered a tiny part of 240,000,000 farmers in China.

\section{THE EFFECT OF GAP ON MINIMIZING FOOD SAFETY RISK}

\section{Performance of GAP}

"Sound agro-environment is the prerequisite of producing sound food (Nanseki, 2008ab)", which well expresses the principle of ChinaGAP. ChinaGAP raises the standardization level of agricultural production and improves agricultural products' quality by controlling agro-environment through standardizing agricultural production. Farming keeping to ChinaGAP standards will effectively reduce risk existing in agricultural production and improve agricultural products' quality. The data from an experiment analyzing impact on milk quality by implementing GAP 2006 showed that the number of somatocyte in milk declined significantly (See Table 4), which indicated the number of bacteria in milk decreased. It is obvious that implementation of GAP resulted in a positive effect on preventing risk and ensuring food safety. Meanwhile the protein and fat content of milk, important indicators of milk quality, soared after implementing GAP (See Table 5, Table 6), which directly reflect milk quality is significantly higher than that of before implementing GAP. These facts support that milk

Table 4. change of the number of stomatocyte after implementing GAP (unit: *103/ml)

\begin{tabular}{lcccccc}
\hline \multicolumn{1}{c}{ Farm Number } & No. 1 & No. 2 & No. 3 & No. 4 & No. 5 & No. 6 \\
\hline Before implementing GAP & 989.5 & 1399.5 & 1075.8 & 223.1 & 318.0 & 543.5 \\
After implementing GAP & 452.0 & 595.0 & 594.2 & 121.9 & 156.2 & 179.7
\end{tabular}

Source of data: Junming et al. (2009) 
Table 5. change of the protein content of milk after implementing GAP (unit: \%)

\begin{tabular}{lcccc}
\hline \multicolumn{1}{c}{ Farm Number } & No. 1 & No. 2 & No. 3 & No. 4 \\
\hline $\begin{array}{l}\text { Before implementing } \\
\text { GAP }\end{array}$ & 3.27 & 3.47 & 2.87 & 3.17 \\
$\begin{array}{l}\text { After implementing } \\
\text { GAP }\end{array}$ & 3.60 & 3.57 & 3.03 & 3.23 \\
\hline
\end{tabular}

Source of data: Junming et al. (2009)

Table 6. change of the fat content of milk after implementing GAP (unit: \%)

\begin{tabular}{lcccc}
\hline \multicolumn{1}{c}{ Farm Number } & No. 1 & No. 2 & No. 3 & No. 4 \\
\hline $\begin{array}{l}\text { Before implementing } \\
\text { GAP }\end{array}$ & 3.93 & 4.13 & 3.69 & 3.15 \\
$\begin{array}{l}\text { After implementing } \\
\text { GAP }\end{array}$ & 4.13 & 4.33 & 4.22 & 3.57 \\
\hline
\end{tabular}

Source of data: Junming et al. (2009)

quality is improved availably by implementing GAP (Junming et al., 2009).

\section{Positive Feedback from Consumers}

Affected by the frequent and enormous amount of reports of food safety accidents in China, oversea consumers have decreased their confidence on food imported from China. As the response, inspection on food imported from China is undertaken extremely strict in some countries. In order to improve quality of export food and rebuild oversea consumer confidence, many Chinese enterprises produce agricultural production in accord with the standards of GAP, which help minimizing risk and ensuring food safety. It is proved by the data of ChinaGAP certification and agricultural production export (See Fig. 6). Now there are 345 valid GAP certificates in China, Fig. 6 shows the distribution of enterprises that have been issued ChinaGAP certificates. Fujian province, Shandong province, Guangdong province, Sichuan province, Hebei province, Shanxi province, Beijing, Anhui province, Jiangsu province, and Shanghai rank the top 10 regions having the most certificates. Fig. 6 shows also that the situation of regional agricultural production exports 2008, Shandong province, Guangdong province, Liaoning province, Zhejiang province, Fujian province, Jiangsu province, Beijing, Shanghai, Jilin province, and Hebei province are the top 10 regions exporting the most agricultural commodities. Obviously, the rankings of top 10 regions having the most certificates are very similar to the top 10 regions exporting the most agricultural commodities. In other words, the enterprises who produce agricultural goods according to standards of ChinaGAP, mainly located in exporting regions, most of which are export enterprises based in the coastal area.

Through exporting safe and high-quality agricultural production to oversea markets, the enterprises not only gain profits, but also win oversea consumer confidence.

\section{CONCLUTION}

With frequent outbreaks of foodborne disease, a series of modern food safety approaches have been taken within every section in food supply chain. Good Agricultural Practices (GAP), as having a prominent impact on reducing risk in the agricultural production from the headstream of food supply chain, has been implemented round the world. Consulting under relevant standards of EUREPGAP, and combining with Chinese current situation, national laws and regulations frame-

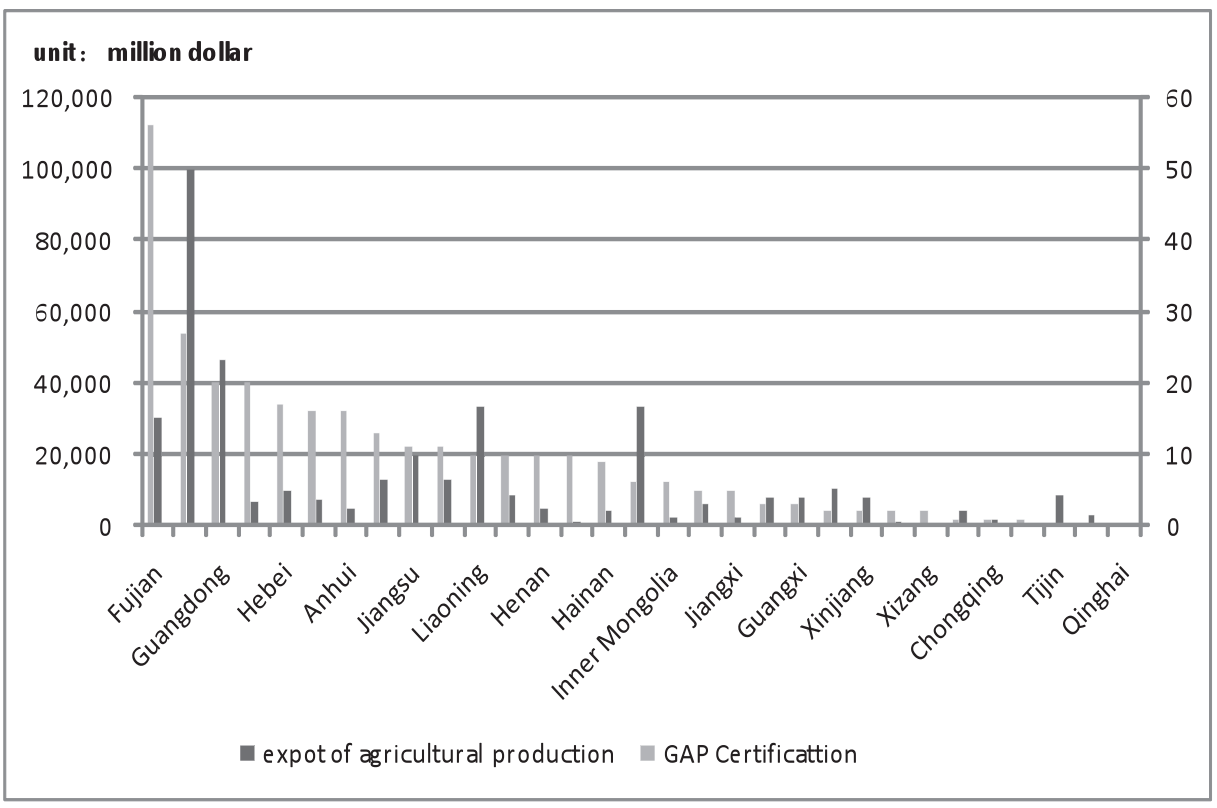

Fig. 6. The distribution of ChinaGAP certificates and the situation of agricultural production export. Source of data: Certification and Accreditation Administration of the P.R.C.; Ministry of Commerce of P.R.C. 
work, China Good Agricultural Practices (ChinaGAP) was set up gradually and developed rapidly with the promotion of government. It has been proved to be an effective way of reducing risk in agricultural production and promoting export. However, the certification mainly focus on export enterprises, only a few domestic smallscale farmers and consumers know it, so it faces the challenge of how to facilitate good agricultural practices on a large scale. There are 240,000,000 small-scale famers in China who can't afford the certification fee or even can't understand the standards of GAP, which is the key hurdle to popularize GAP broadly. Here are two possible solutions: on one hand, organizing farmers in different cooperative models, such as "company + small-scale farmers" or famers cooperation organization; on the other hand, enhancing farmers' capability by means of educational and technical training programme.

\section{REFERENCES}

AQSIQ 2009 China GAP gained international mutual recognition. http://english.aqsiq.gov.cn/NewsRelease/NewsUpdates/ 200903/t20090326_109768.htm
Bai, Li et al. 2007 Food safety assurance systems in China. Food Control, 18: 480-484

Jie, Lv et al. 2009 Application Situation and Study on the Good Agriculture Practices (GAP). Journal of Anhui Agricultural Science, 37(12): 5812-5813, 5816

Junming, Zhang et al. 2009 Ensuring Dairy Safety Through implementing GAP. 2009 International GAP Forum, 141144

Matsuda, Tomoyoshi 2007 Gap As a Baseline, Traceability As a Pipeline to Build Consumer Confidence. http://www.agnet. org/library/bc/54001/

Nanseki, Teruaki 2008a Perception and Management of Risk in Food and Agriculture. Food Safety and Risk in Agriculture, Proceedings of Resources and Environment in East Asia: Perspectives of Technology Development and System Design. the Faculty of Agriculture, Kyushu University, 13-23 (in Japanese)

Nanseki, Teruaki 2008b International Network for Integrated Risk Research on Environment and Food. Food Supply Chain and Safety. Chinese Academy of Agricultural Science Press, 54-68 (in Japanese)

Song, Min et al. 2008 Consumers' Attitudes to Food Traceability System in China-Evidences from the Pork Market in Beijing. Journal of Faculty of Agriculture of Kyushu University, 53(2): 569-574 